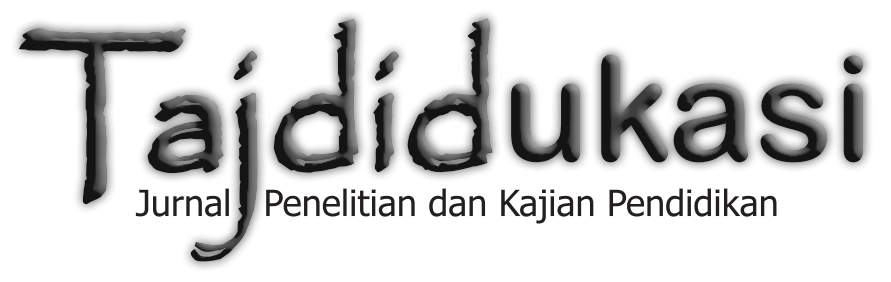




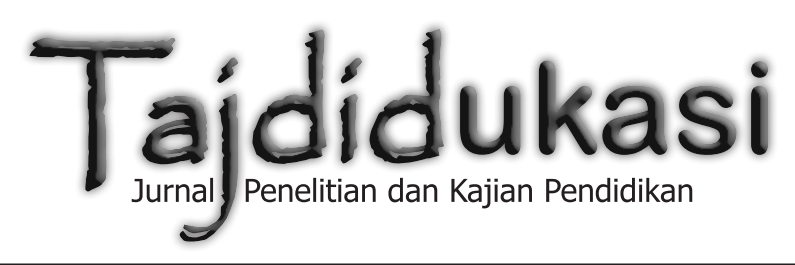

Volume VIII, No. 2, Juli 2018

ISSN: 1979-6943

Tajdidukasi: Jurnal Penelitian dan Kajian Pendidikan merupakan jurnal Penelitian dan Kajian Pendidikan yang berisi Penelitian Tindakan Kelas (PTK) dan Penelitian Tindakan Sekolah (PTS) serta Kajian Pendidikan interdisipliner di Perguruan Tinggi yang diterbitkan Majelis Pendidikan Dasar dan Menengah Pimpinan Wilayah Muhammadiyah Daerah Istimewa Yogyakarta. Artikel hasil PTK dan PTS serta kajian pemikiran pendidikan ditulis oleh para Guru dan Kepala Sekolah serta Dosen dalam mengujicobakan metode dan strategi pembelajaran untuk meningkatkan kualitas pendidikan baik SD/MI, SMP/MTs dan SMA/MA/SMK serta Perguruan Tinggi. Artikel PTK dan PTS fokus pada mata pelajaran di sekolah/madrasah, seperti Ilmu Pengetahuan Alam (IPA), Imu Pengetahuan Sosial (IPS), Matematika, Fisika, Kimia, bahkan teknik, seperti Teknik Mesin, Elektro, Informatika dan lain sebagainya. Sementara itu, artikel Kajian Pendidikan merupakan penelitian interdisipliner dan multidisipliner yang dilakukan Dosen di Perguruan Tinggi terhadap khasanah keIslaman.

Tajdidukasi: Jurnal Penelitian dan Kajian Pendidikan adalah jurnal terbuka yang versi softfile-nya bisa dibaca dan diakses secara gratis, sementara versi print out/ hardcopy dapat diperoleh dengan menghubungi distributor di alamat serial tajdidukasi.ac.id. Sof-file keseluruhan artikel yang diterbitkan dapat diakses melalui Tajdidukasi Open Access Juornal di www.dikdasmenpwmdiy.or.id

Pimpinan Editor
Suyadi, Universitas Ahmad Dahlan (UAD) Yogyakarta, Indonesia

Anggota Editor

Arif Budi Raharjo, Universitas Muhammadiyah Yogyakarta (UMY), Indonesia

Achmad Muhammad, UIN Sunan Kalijaga Yogyakarta, Indonesia

Hendro Widodo, Universitas Ahmad Dahlan (UAD) Yogyakarta

Mundzirin Yusuf, UIN Sunan Kalijaga Yogyakarta, Indonesia

Sumedi, UIN Sunan Kalijaga Yogyakarta, Indonesia

Sukamto, Universitas Muhammadiyah Yogyakarta (UMY), Indonesia

Sumarsono, UIN Sunan Kalijaga Yogyakarta Indonesia

Sarjilah (Lembaga Penjaminan Mutu Pendidikan) Yogyakarta

Fathur Rahman, M.Si., Universitas Negeri Yogyakarta (UNY) Indonesia

\section{Editor Pelaksana}

Suryanto, Universitas Muhammadiyah Yogyakarta (UMY), Indonesia

Suyatno, Universitas Ahmad Dahlan (UAD) Yogyakarta

Farid Setiawan, Universitas Ahmad Dahlan (UAD) Yogyakarta

Alamat Redaksi:

Kantor Majelis Pendidikan Dasar dan Menengah Pimpinan

Wilayah Muhammadiyah D.I. Yogyakarta

J1. Gedongkuning No. 130B Yogyakarta

Kode Pos : 55171

Telephone : (0274) 377078

Facsimile : (0274) 371718

Website : www.dikdasmenpwmdiy.or.id

E-Mail : tajdidukasi@dikdasmenpwmdiy.or.id 


\title{
REKONSTRUKSI FILSAFAT TARBIYAH (Telaah Atas Pemikiran Abbas Mahjub)
}

\author{
Suyadi \\ Universitas Ahmad Dahlan \\ suyadi@fai.uad.ac.id
}

\begin{abstract}
Abstrak
Filsafat pendidikan hingga saat ini dianggap tidak ada, kecuali s ebatasi uraian dogmadogma agama. Padahal, pendidikan Islam beserta seluruh dimensinya bertumpu pada bangunan filsafat pendidikan Islam tersebut. Dalam kondisi yang demikian, Abbas Mahjub tampi mengisi kekosongan dengan menawarkan pencerahan, bahwa filsafat pendidikan merupakan derifasi dari filsafat Islam. Menurutnya, ontologi atau metafisika pendidikan Islam adalah ma'rifatllah, epistimologi pendidikan Islam adalah penyucian jiwa dan aksiologi pendidikan Islam adalah kemaslahatan. Di atas bangunan filsafat pendidkan inilah dapat dibangun ilmu dan teori pendidikan Islam serta tujuan, materi dan metode pembelajaran keagamaan Islam.
\end{abstract}

Kata kunci: Filsafat, Pendidikan, dan Islam

\section{A. PENDAHULUAN}

Filsafat pendidikan Islam (selanjutnya disebut filsafat tarbiyah) dapat dipahami sebagai pemikiran radikal, mendalam, ktiris dan sistematis dari seorang filsuf muslim. Hingga saat ini, telah banyak filsuf muslim yang menaruh perhatian serius pada tarbiyah, sehingga hasil pemikirannya tersebut dianggap sebagai filsafat tarbiyah. Beberapa filsuf muslim yang dapat disebut di sini adalah Al-Ghazali, Ibn Sina, In Khladun, Ibnu Khaldun, al Qabisi, Ibnu Sahnun dan lain sebagainya. Namun demikian, pemikiran para filsuf muslim tersebut sesungguhnya bukanlah filsafat tarbiyah, melainkan sebatas pemikiran tentang filsafat tarbiyah.
Dari sekian banyak filsuf muslim yang ada, Abbas Mahjub merupakan salah satu filsuf muslim yang menaruh perhatian serius untuk memikirkan tarbiyah. Menurutnya, filsafat pendidikan tidak sebatas pemikiran para filsuf di bidang pendidikan, melainkan para filsuf itulah yang layak disebut pendidik. Abbas Mahjub menyatakan:

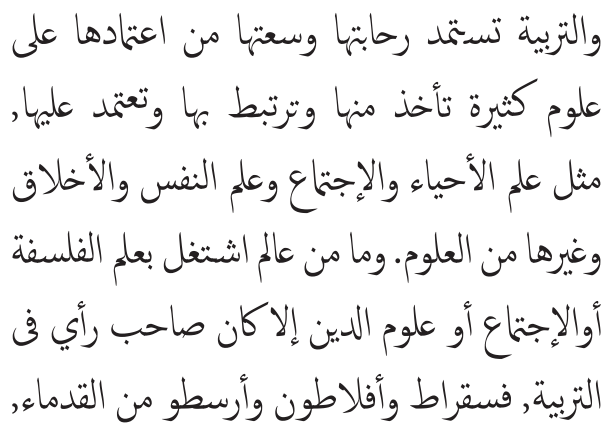
علوم كثيرة تأخذ منها وترتبط بها وتعتمد عليها, مثل علم الأحياء والإجتماع وعلم النفس والأخلاق وغيرها من العلوم. وما من عالم اشتغل بعلم الفلسفة

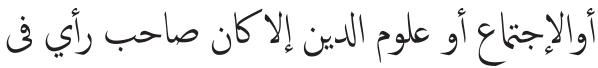
التربية, فسقراط وأفلاطون وأرسطو من القدماء, 
وابن سينا والغزالى وابن خلدون والقابسى وابن سحنون وغير هم من المسلمين, وبستالوتزى وجون ونين ديوى وجان جاك روسو وغيرهم من المحدثين اشتغلوا بلفلسفة وأصلوا كثيرا من النظريات ونم من الندين

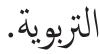

Terjemahan bebasnya:

"Pendidikan mengambil ruang lingkupnya dari ilmu yang kompleks, seperti ilmu biologi, limu sosial, ilmu jiwa dan akhlak maupun yang lainnya. Tidak ada orang yang berpengetahuan filsafat atau social atau ilmu-ilmu agama kecuali ia adalah orang berpendidikan. Oleh karena itu Sokrates, Plato, Aristoteles dari kelompok klasik (masa lalu), dan Ibnu Sina, al Gazali, Ibnu Khaldun, al Qabisi, Ibnu Sahnun dll dari umat Islam, Pestalozi, J.Dewew, J.J Roussou dan lain-lainnya dari para modernis yang telah mendalami filasafat mereka itu telah menghasilkan banyak teoriteori pendidikan" (Mahjub, 1987: 23).

Berdasarkan pernyataan Abbas Mahjub di atas, para filsuf telah banyak melahirkan teori pendidikan. Artinya, dari para filsuf itulah sebenarnya filsafat pendidikan telah dibangun, karena mustahil teori pendidikan dapat dilahirkan tanpa bangunan filsafat pendidikan. Hal ini diperkuat dengan pernyataan Abbas Mahjub yang menegaskan bahwa:

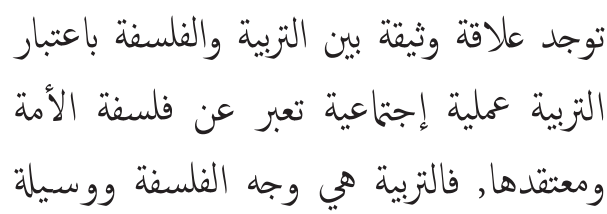

إبرازها للوجود وتطبيقها فى الواقع, وهي روه الأمة المعبرة عنها وعن أهدافها وتطلعاتها في الحياة.

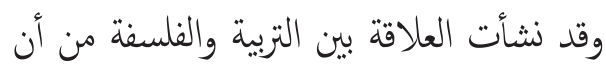
التربية وليدة الفلسفة وخلاصة التجارب والآراء التى توصلت الفلسفة إليها, فالتجمة هي الترجمة ولتها العملية الواقعة للفلسفة, وهي التى تنقل الفلسفة من مجال النظرية والفكرة إلى مجال الواقع الإنسانى والمارسة الحياتية.

Terjemahan bebasnya:

"Antara filsafat dan pendidikan, terdapat hubungan yang erat, dimana pendidikan merupakan praktek sosial yang menggambarkan falsafah dan keyakinan umat/bangsa. Pendidikan adalah wajah filsafat dan media untuk menampakkan eksistensi dan praktek filsafat dalam kehidupan. Filsafat itu merupakan ruh atau jiwanya ummat yang menggunakannnya dan mewujudkan tujuan serta harapan-harapannya dalam kehidupan. Hubungan antara pendidikan dan filsafat adalah pendidikan merupakan anak-turunan filsafat dan intisari dari berbagai eksperimen dan pendapat yang telah dicapai filsafat. Oleh karena itu pendidikan merupakan tafsiran praktis realistis bagi filsafat, ia (pendidikan itu) memindahkan filsafat dari yang teoritis dan pemikiran ke lapangan relaitas manusia dan dapat dipraktekkan dalam kehidupan" (Mahjub, 1987: 23).

Berdasarkan peryataan Mahjub di atas, jelas bahwa posisi filsafat tarbiyah 
adalah turunan dari filsafat Islam ( $\mathrm{Al}$ Falsafah Al-Islamiyah). Hanya di atas pondasi filsafat tarbiyah inilah dapat dibangun ilmu tarbiyah dan teori tarbiyah sehingga tarbiyah dapat dipraktekkan. Namun demikian, Abbas mahjub justru tidak membahas konstruksi filsafat tarbiyah tersebut dalam, "Us- Ül Al Fikriy Al Tarbawiy F̄̄ Al Islām”. Padahal, sebelumnya Abbas Mahjub meyatakan bahwa para filsuf adalah para pendidik yang telah banyak melahirkan teori pendidikan.

Berdasarkan analisis dalam studi pendahuluan di atas ditemukan bahwa Abbas Mahjub tidak membahas konstruksi filsafat tarbiyah secara utuh. Namun demikian, ia telah melahirkan ilmu dan teori bahkan praktek tarbiyah secara komprehensif. Jika analisis studi pendahuluan ini dilukiskan dalam bentuk skema, akan tampak sebagai berikut.

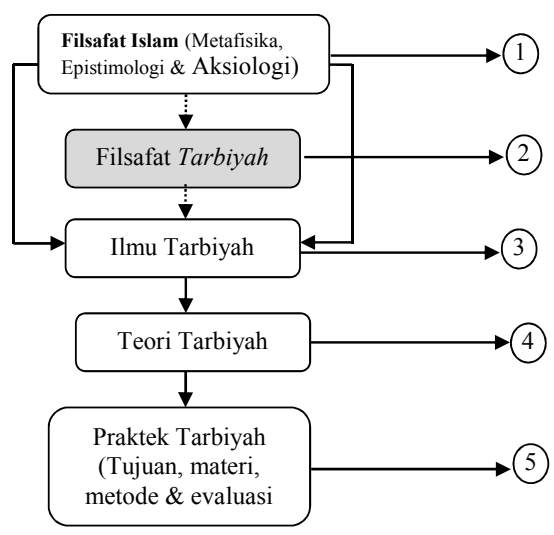

Ketereangan Gambar Berdasar Pembahasan dalam "Us Ūl Al Fikriy Al Tarbawiy F̄̄ Al Islām” Karya Abbas Mahjub

1. Diulas pada pengantar dan pendahuluan.

2. Belum dibahas Abbas Mahjub, olehkarena itu menjadi fokus dalam penelitian ini.

3. Dibahas pada bab I (Ilmu dan pembelajaran dalam Islam dan bab II (Pendidikan sebelum dan sesudah Islam).

4. Dibahas pada bab III (Basis-basis Pendidikan dalam Islam).

5. Dibahas pada bagian bab IV (Tujuan-tujuan Asasi dari Pendidikan Islam), Bab V : Aspek-aspek Pendidikan dalam Islam, Bab VI : Pendidikan Islam dan Fase-fase Perkembangan, Bab VII :

Lingkungan Pendidikan dalam Islam \& Bab VIII : Sarana Pendidikan dalam Islam.

Gambar: 1

Telaah “Us $\bar{U}$ I Al Fikriy Al Tarbawiy Fì Al Islām”"karya Abbas Mahjub

Berangkat dari temuan sebagaimana ditunjukkan pada gambar 1 di atas, penelitian ini difokuskan pada konstruksi filsafat tarbiyah, dimana bahan atau kerangka maupun konstruksinya diambil dari ilmu, teori dan praktek tarbiyah yang dikemukakan Abbas Mahjub dalam karyanya "Us $\overline{U l}$ Al Fikriy Al Tarbawiy Fì Al Islām”.

Dengan demikian, tujuan dari pene- litian ini adalah melakukan rekonstruksi filsafat tarbiyah berdasarkan teori dan praktek yang disusun Abbas Mahjub. Untuk mencapai tujuan tersebut, dilakukan penelitian kepuastakaan dengan kerangka teori filsafat pendidikan George R. Knight dan menggunakan pendekatan filosofis kritis. Dengan tercapainya tujuan dalam penelitian ini diharapkan dapat berguna bagi pengem- 
bagan filsafat tarbiyah ke masa depan.

Filsafat tarbiyah adalah turunan dari filsafat Islam. Di atas banguna filsafat tarbiyah tersebut dapat dibangun ilmu tarbiyah. Di atas ilmu tarbiyah dapat dibangun teori-teori tarbiyah dan berdasarkan teori yang disusun dapat dilakukan praktek tarbiyah. Jika kerangka ini dilukiska dalam bentuk skema, akan tampak sebagai berikut.

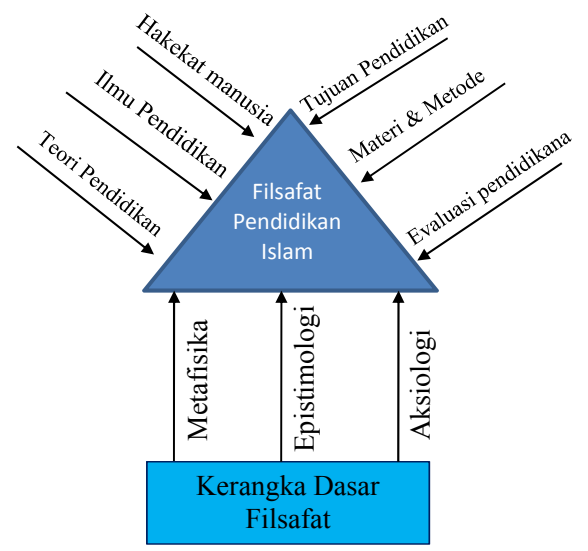

Gambar: 2

Kerangka Pikir Penelitian diadopsi dari Filsafat Pendidikan Georgi R. Knight.

Selanjutnya, kerangka pikir penelitian tersebut dikontekstualisasikan pada ranah yang lebih spesifik, yakni filsafat tarbiyah. Oleh karena itu, kerangka pikir penelitian ini dimulai dari falasafah Islam, filsafat tarbiyah, ilmu tarbiyah, teori tarbiyah dan praktek tarbiyah.

Berikut ini dikemukakan hasil analisis dan pembahasan dalam upaya menyusun konstruksi filsafat tarbiy$a h$. Sesuai dengan kerangka teori dan metode yang ditempuh dalam penelitian, pembahasan ini mengikuti alur konstruksi filsafat pendidikan George R.
Knight (Knight, 2007:25) yang kemudian diadopsi untuk menyusun konstruksi filsafat tarbiyah.

\section{B. Kerangka Dasar Filsafat Tarbiyah}

Kerangka dasar filsafat terdiri dari tiga eleman, yakni metafisika, epistimologi dan aksiologi (Arif, 2011: 21). Oleh Karen itu, konstruksi filsafat tarbiyah juga akan dibangun di atas tiga kerangka dasar ini.

\section{Metafisika}

Metafisika adalah cabang filsafat yang membicangkan hakekat realitas segala yang "ada". Pertanyaan mendasar dalam diskursus metafisis adalah, "Apakah sesuatu yang benar-benar 'ada' itu 'ada'? Apakah sesuatu yang "tidak ada" itu "ada" (Mulkhan, 1993: 35) dan seterusnya. Dalam konteks menelusuri jejak metafisika Abbas mahjub dalam karyanya "Us Ūl Al Fikriy Al Tarbawiy Fì Al Islām", dapat ditemukan dalam "Pendahuluan", khususnya pada sub bab "Filsafat Pendidikan Islam dan Karakteristiknya". Dalam "Pendahuluan" ini Abbas Mahjub menyatakan bahwa:

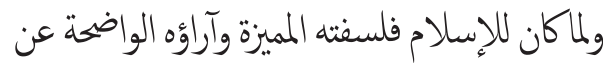
الله والكون والإنسان والوجود, ومفاهمة الواضحة

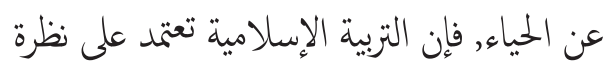

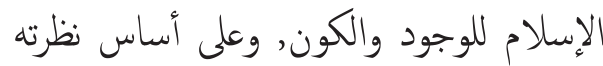
للحقائق المادية والروحية في الكون والإنسان وعلى الكان

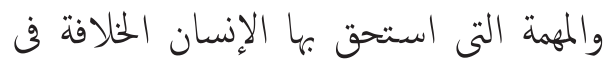

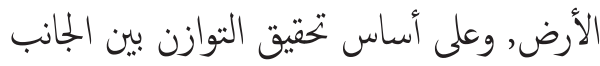


الروحى فى الإنسان والجانب المادى فيه

Terjemahan bebasnya:

"Ketika Islam itu memiliki filsafatnya yang khas dan pandangan-pandangannya yang jelas dari Allah, alam, manusia, apa yang ada (al wujūd), dan pandangannya yang jelas tentang kehidupan, maka sesungguhnya pendidikan Islam itu bersandar pada pandangan Islam tentang apa yang ada dan alam, dan bersandar pada prinsip pandangan Islam tentang hakekat materi dan immateri (rūhiyyah) di alam ini dan manusia, urgensi khilafah yang dimiliki manusia serta bersandar pada prinsip mewujudkan keseimbangan antara aspek ruhani dan aspek jasmani dalam diri manusia" (Mahjub, 1987: 35).

Pernyataan Abbas Mahjub di atas menunjukkan bahwa realitas pendidiikan atau lebih kongkritnya adalah kegiatan dalam praktek tarbiyah bukan realitas sederhana sebagaimana tampak adanya. Di balik itu terdapat seperangkat pendidikann yang sangat kompleks, dan di balik itu semua terdapat sistem filsafat pendidikan yang hakiki. Dalam hal ini, realitas terdalam pada puncaknya akan sampai pada dunia "ide" sebagaimana dikemukakan Plato (Barnadaib, 1994: 60). Realitas puncak atau dunia ide tersebut dalam bahasa filsafat Islam disebut dengan iitilah emanasi, dan dalam istilah Mahjub disebut dengan ma'rifat. Jadi, hakekat segala yang ada, termasuk yang tidak ada (karena yang tidak ada itu adala ada) yakni "ide" (dalam Istilah Plato), emanasi dalam istilah filsug Muslim dan makrifat (dalam istilah Abbas Mahjub).

2. Epistimologi

Epistimologi, sebagaimana metafisika berada pada dasar pemikiran dan aktivitas manusia. Epistimologi memberi pengaruh langsung terhadap pendidikan dalam berbagai bentuk, khsusnya bagaimana cara yang ditempuh manusia untuk memperoleh pengetahuan. Dalam konteks ini, epistimologi Abbas Mahjub bertumpu pada dimensi biokimiawi manusia yang kemudian melakukan berbagai aktifitas untuk memperoleh kebenaran sejati sehingga mengantarkannya pada maqomat ma'rifat. Ia menyatakan, فالعلم هو الطريق الحق (Ilmu adalah jalan yang benar untuk ma'rifat kepada Allah dengan sarana pembelajaran) (Mulkhan, 1993: 41). Berdasarkan pernyataan Mahjub ini, dapat dipahami bahwa cara mencapai maqom ma'rifat adalah dengan ilmu. Ilmu yang dimaksud adalah sebagaimana yang dibahas pada bab empat dan lima, yakni mengenai tujuan asasi pendidikan Islam dan aspek-aspek pembelajaran. Inti dari pembehasan tersebut adalah "penyucia jiwa". Jadi, ilmu yang mengantarkan peserta didik pada maqom ma'rifatmenurut Mahjub-dapat ditempuh dengan penyucian jiwa.

3. Aksiologi

Aksiologi adalah kerangka dasar filsafat tentang nilai, manfaat, kegunaan maupun fungsi dari obyek yang diperbicangkan secara filosofis (Qomar, 2002: 
1). Dalm konteks ini, dimensi aksiologis Us_ Ūl Al Fikriy Al Tarbawiy Fī Al Islām" karya Abbas mahjub dapat ditelusuri pada bab tiga, khususnya pasal tiga dan empat. Pada bagian tersebut Ia menyatakan bahwa:

ومع ذلكفإننا نلاحظ فى الدول التى أخذت بنظام تحديدالنسل كثيرا من المشكلات تالإقتصادية والتفكك اله سري والحيرة فن أوساط الشباب, بل إن دولا إسلامية أخذت بهذا النظام وجندت

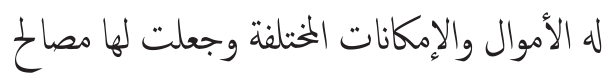
قائمة بهذا الأمر , إلا أنها فشلت فن ذلك لتعارض الفكرة مع الفطرة السلمية بل المسلمة

Terjmahan bebasnya:

"Bersamaan dengan itu, kita sesungguhnya memperhatikan negara-negara yang banyak mengambil sistem pembatasan keturunan itu pada bentuk-bentuk ekonomi, pemisahan, perjalanan dan keraguan di dalam tengah-tengah pemuda. Tetapi negara Islam mengambil sistem ini, menjaga harta-hartanya, tempat-tempat yang berbeda dan menjadikannya kemaslahatan-kemaslahatan yang bernilai dengan dengan perintah ini. Kecuali gagal dalam melawan pikiran yang bersamaan dengan fitrah keselamatan dan bahkan yang diselamatkan” (Mahjub, 1987: 111).

Berdasarkan pernyataan Abbas di atas, dapat dipahami bahwa kerangka dasar aksiologi filsafat pendidikan Islam adalah optimalisasi potensi atau fitrah sehingga menghasilkan nilai-nilai kemaslahatan untuk membangun sistem kenegaraan yang lebih bermatabat.

\section{Jejak Filsafat Tarbiyah dalam Praktek}

Sebagaimana disebutkan di depan, bahwa Abbas Mahjub tidak membahas filsafat tarbiyah secara utuh, namun ia telah membahas teori dan praktek tarbiyah secara komprehensif. Oleh karena itu, filsafat tarbiyah dapat ditelusuri melalui jejak-jejak yang ditinggalkan dalam teori dan praktek tarbiyah. Salah satu jejak tersebut adalah pernyataan Mahjub mengenai hubungan filsafat Islam dan filsafat pendidikan. Ia menyatakan:

"Sesungguhnya pendidikan Islam itu sesuai dengan filsafat Islam ... pendidikan merupakan praktek sosial yang menggambarkan falsafah dan keyakinan umat/bangsa. Pendidikan adalah wajah filsafat dan media untuk menampakkan eksistensi dan praktek filsafat dalam kehidupan. Filsafat itu merupakan ruh/jiwanya ummat yang menggunakannya dan mewujudkan tujuan serta harapan-harapannya dalam kehidupan" (Mulkhan, 1993: 29).

Berdasarkan pernytaan Mahjub di atas, jelas bahwa pendidikan itu adalah praktek dari filsafat. Oleh karena itu, filsafat pendidikan adalah filsafat dalam praktek. Bagaikana komputer, filsafat adalah software-nya dan pendidikan merupakan hardware-nya, atau dalam analogi lampu sorot, filsafat adalah energy atau baterainya sedangkan pendidikan adalah cahaya yang dihasilkannya. Lebih tegas lagi, Mahjub 
menytakan bahwa "Pendidikan adalah anak/turunan filsafat dan intisari dari berbagai eksperimen dan pendapat yang telah dicapai filsafat" (Mulkhan, 1993: 329).

Selanjutnya, filsafat tarbiyah dikembangkan berpangkal dari pandangannya terhadap manusia. Abbas Mahjub menyatakan bahwa Filsafat pendidikan Islam berdiri di atas hal-hal yang telah ditetapkan Al-Qur'an dan yang telah dijelaskan As-Sunnah berupa eksistensi hakekat materi dan immaterial dalam realitas karakter penciptaan manusia yaitu dibentuk berdasarkan prinsip bahwa manusia itu yang tunduk terhadap proses pendidikan itu terdiri dari materi dan ruh /immateri" (Mulkhan, 1993: 29). Artinya, filsafat tarbiyah sebagai sumber energi sebuah lampu, misalnya, berorientasi pada terangnya cahaya yang dihasilkan. Kualitas pendidikan dalam mengoptimalisasikan fitrah atau potensi manusia (peserta didik) ditentukan oleh filsafat tarbiyah yang ada di dalamnya. Tanpa filsafat tarbiyah, fitrah peserta didik tidak akan dapat berkembang dengan baik. Dari sini, teori dan praktek tarbiyah dapat disusun berdasarkan keseimbangan antara materi dan immateri atau dalam analogi computer keseimbangan hardware dan software.

Dengan demikian, jejak filsafat tarbiyah sesunguhnya telah tampak jelas dalam teori dan praktek pendidikan, yakni keseimbangan antara dimensi jasmani dan ruhani dengan berpedoman pada filsafat Islam yang bersumber pada al-Qur'an dan Sunnah.

\section{Hakekat Manusia}

Sebagaimana disebutkan di depan, bahwa filsafat tarbiyah bertumpu pada cara pandang terhadap hakekiat manusia sebagai peserta didik. Dalam hal ini, Abbas Mahjub memandang bahwa hakekat manusia adalah 'biokimia' yang di dalamnya bersemayam ruh dan jiwa. Devinisi ini didasarkan pada salah satu hadits Rasulullah Saw., khususnya yang terkait dengan proses penciptaan manusia. Abbas Mahjub menyatakan:

"Islam melihat sisi manusia mempunyai tabiat yang melekat pada dirinya, yaitu tempat dimana hidup ruh dan biokimia.... Rasulullah SAW menyampaikan bahwa proses pencipataan biokimia badan manuasia dimulai dari air mani kemudian menjadi segumpal darah, kemudian menjadi segumpal daging dan kemudian ditiupkannya ruh" (Mahjub, 1987: 51).

Berdasarkan pernyataan Abbas mahjub di atas, dapat dipahami bahwa hakekat manusia terdiri dari dua unsur, yakni jasmani (biologi) dan rohani (kimiawi). Hal ini berbeda dengan pandangan manusia oleh para filsuf muslim yang lain — salah satunya adalah Muhammad Qutb-yang membagi manusia menjadi tiga unsur, yakni jasmani, ruhani dan akal (Qutb, 1988: 31). Jika para filsuf pada umumnya menempatkan akal pada posisi atau unsur penting yang membedakannya dengan makhluk lain, tidak demikian dengan Abbas Mahjub. Bagi Mahjub, bukan akal yang menjadi unsur penting sehingga 
membedakannya dengan makhluk lain, tetapi ruh. Ia menyatakan:

"Unsur khusus inilah (roh), yang membedakan antara manusia dengan hewan, mengangkatnya dalam alam ruh, menjadikannya memiliki sifat para malaikat yakni tidak pernah durhaka pada Allah terhadap apa yang diperintahkan dan selalu melaksanakan apa yang diperintahkan, serta selalu mensucikan Allah baik malam ataupun siang dan mereka dianugerahi dengan 'arsy-Nya .... Pada umumnya ruh akan ditemukan ketika manusia menempati kedudukan ma'rifat dan mengadakan perenungan" (Mahjub, 1987: 72).

Meskipun Abbas Mahjub tidak menyebut unsur akal sebagaimana para filsuf yang lain, tetapi ia merujuk ruh pada maksud perenungan dan pemikiran. Selanjutnya, Abbas Mahjub juga menyamakan antara ruh dan jiwa atau hati sebagaimana emosi dan akal. Mahjub memperkuat argumennya ini dengan menyandarkan pada salah satu hadis yang berbunyi, "Ingatlah sesusungguhnya dalam jasad manusia ada segumpal daging, yang apabila itu baik maka baiklah seluruh jasad, dan apabila daging itu jelek maka jeleklah seluruh jasad, itulah yang disebut hati'. Kemudian, Mahjub menjelaskan bahwa, ".....perasaan hati yang ada pada diri manusia.....demi hidupnya perasaan hati manusia, dijadikannya didalam tingkah yang terang" (Mahjub, 1987: 97).

Berdasarkan pembahasan megenai hakekat manusia menurut Abbas mah- jub di atas, dapat disimpulkan bahwa hakekat manusia terdiri dari dua unsur, yakni jasmani dan ruhani yang oleh Mahjub disebut dengan istilah "biokima". Artinya, "bio" dimaknai sebagai jasmani dan "kimia' dimaknai jiwa atau nyawa (jw) maupun se-nyawa kimia. Dalam pengertian ini, Mahjub menyamakan antara ruh, jiwa dengan hati dan perasaan. Perlu digaris bawahi, bahwa entitas "kimia" atau ruh, jiwa, hati dan perasaan adalah untuk merenung dan berpikir agar meraih kedudukan ma'rifat. Konsep kedudukan ma'rifat dalam pemikiran Abbas mahjub ini bersesuaian dengan konsep kecerdasan ma'rifat yang digagas Abdul Munir Mulkhan (Mulkhan, 1993: 36).

\section{E. Hakekat Ilmu Tarbiyah}

Bertumpu pada hakekat manusia, yang salah satu ciri khasnya adalah mempunyai dimensi materi dan imateri atau kimiawi, akal, emosi, perasaan dan sejenisnya, maka tidak sulit bagi manusia untuk menyusun ilmu pengetahuan. Ilmu pengetahuan adalah serangkaian pengalaman, pemikiran, ide, gagasan dan sejenisnya yang disusun secara sistematis. Dalam hal ini, Abbas Mahjub membagi ilmu menjadi dua, yakni ilmu hakikat dan ilmu dzahir. Selanjutnya, ilmu yang sempurna adalah keseimbangan diantara keduanya. Kesempurnaan ilmu tersebut pada hekekatnya adalah jalan keselamatan. Ia menyatakan:

"Sesungguhnya ilmu yang lebih utama bagi umat tidak sempurna kecu- 
ali dengan penataan nilai perilaku dan ilmu terapan. Dan hakikat ilmu yang menyelamatkan adalah menata jalan atau perbuatan. Bagi seorang muslim tidak menulis satu huruf atau berkata satu kata atau sepintas dengan melihat kecuali dengan adanya bekal ilmu... Ini adalah azaz pembahasan ilmu yang menjadi bangunan dari ilmu hakikat dan ilmu dhohir". (Mahjub, 1987: 105).

Tidak jelas apa yang dimaksud Mahjub dengan ilmu hakekat dan ilmu dzahir sebagaimana disebutkan di atas. Namun jika dilihat dari pembahasan pada bagian-bagian yang lain dalam " $U s$ Ūl Al Fikriy Al Tarbawiy Fì Al Islām" ini, terdapat indikasi kuat bahwa yang dimaksud ilmu hakekat adalah ilmu hati, emosi, perasaan dan sejenusnya. Sedangkan yang dimaksud dengan ilmu dzahir adalah ilmu jasmaniah.

Berdasarkan pandangan ilmu pengetahuan di atas, jelas bahwa ilmu pengetahuan diorientasikan pada upaya mengukap tabir atau rahasia penciptaan semesta, sehingga ditemukan hakekat realitas dari segala yang ada, yakni ma'rifat. Hal ini menunjukkan bahwa Mahjub menaruh perhatian serius pada metafisika ilmu pengetahuan, karena dengan ilmu pengetahuan itu dijadikan sebagai alat untuk menyingkap rahasia Allah. Kemudian, Abbas Mahjub menyebutkan istilah "ma'rifat" sebagai indikasi terbukanya tabir rahasia. Mahjub menyatakan bahwa:

فالعلم هو الطريق الحق لمعرفةالله من خلال دراسة هذا الكون على بدائع صنع الله تعالى, وهوالوسيلة
التى يتحرر بها عقل الإنسان من ربقة الجهل والخزافة والجمود "Ilmu adalah jalan yang benar untuk ma'rifat kepada Allah dengan sarana pembelajaran. Asumsi ini adalah merupakan pemeliharaan dari Allah. Hal itu merupakan sarana untuk merawat akal manusia dari lingkarann kebodohan, ketidakjelasan, dan keterbelakangan" (Mahjub, 1987: 41).

Berdasarkan pernyataan di atas, $\mathrm{Ab}-$ bas Mahjub menyebut bahwa ma'rifat dapat ditempuh melalui pembelajaran. Pembelajaran yang mampu mengantarkan peserta didik meraih ma'rifat itu adalah penyucian jiwa.

\section{F. Teori Tarbiyah}

Berangkat dari hakekat ilmu dzahir dan batin untuk mencapai kedudukan ma'rifat di atas, dapat dibangun beragam teori tarbiyah bahkan teori ma'rifah. Karena salah satu teori ciri adalah dapat dipelajari, maka teori tarbiyah (termasuk teori ma'rifah) juga dapat dipelajari. Secara lebih terperinci, Abbas Mahjub membahas teori-teori tarbiyah dalam " $U s$ Ūl Al Fikriy Al Tarbawiy Fì Al Islām", khususnya pada bab tiga, yang mencakup basis teori aqidah, humanism, fitrah, tanggung jawab, pendidikan akhlak, ibadah, budaya, musyawarah, aspek-aspek pendidikan, seperti: spiritual, emosional, intelektual, kesehatan mental, vokasional dan lain sebagainya.

Pembelajaran merupakan bagian dari berbagai jenis pendidikan. Di 
dalam Islam pembelajaran itu bukan media untuk mendikte pengetahuan, pemikiran, menghafal dan mengulang-ulanginya, tetapi pembelajaran merupakan sarana pendidikan dalam membentuk manusia menghadapi realitas yang ia kehendaki, ia akan tinggal dan masyarakat yang akan berhungan denganya. Dalam hal ini Abbas mahjub menyatakan:

$$
\begin{aligned}
& \text { إنها تعتبر التعليم حقا وواجبا فى حياة الإنسان, } \\
& \text { يأخذ منه ما يستطيع دون حد ولا قيد إلا قيد } \\
& \text { القدرات والإمكانات مات بات }
\end{aligned}
$$

"Sesungguhnya pendidikan itu merupakan pembelajaran yang sesungguhnya dan wajib dalam kehidupan manusia, ia mengambil yang sedapat yang ia lakukan tanpa batasan dan tanpa ketentuan kecuali batasan kemampuan dan kecakapannya" (Mahjub, 1987: 24).

Berdasarkan pernyataan di atas, pendidikan (sebagia gudang teori) terdapat jenjang-jenjang atau tahaptahap maupun maqomat-maqomat. Teori yang dipelajari dalam pendidikan disesuaikan dengaan tingkat maqomat tersebut. Dengan demikian, semakin tinggi maqom atau jenjang pendidikan seseorang, semakin mendalam teori yang dipelajari. Semakin mendalam teori yang dipelajari, semakin menjulang ilmu seseorang. Ketika keilmuan seseorang telah menjulang, maka ia telah sampai pada maqom ma'rifat.

\section{G. Praktek Tarbiyah}

Praktek tarbiyah mencakup tujuan, materi (kurikulum), metode dan evaluasi (Mulyasa, 2007: 15). Tujuan pendidikan bertimpu pada hekekat manusia (makhluk biokimia), materi pendidikan bertumpu pada hekekat ilmu (dzahir dan batin), metode pendidikan bertumpu pada teori pendidikan dan evaluasi pendidikan bertumpu pada pengukuran (maqomat ma'rifat). Dalam hal ini, Abbas Mahjub menyatakan bahwa:

أن المسلمين عرفوا مبادىء التربية وأصولها وممارساتها من القرآن و السنة والعملية والقولية والتقريرية, وقد عدئ كان الرسول صلى الله عليه وسلم وصحابته يتمثلون تربية القرآن فى السلوك اليومى والمعاملات المختلفة بكل أهدافه وأساليبه وخصائصه, وكانوا قدرة حسنة لأجيال عاشت بعدهم وتمسكت بتربيتهر, وتتميز

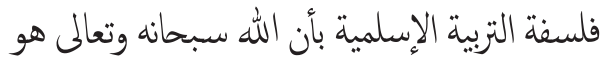
الذى خطط إطارها وحدد أهدافها وبين وسائلها Terjemahan bebasnya:

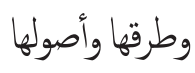

"Sesungguhnya umat Islam itu mengetahui prinsip-prinsip pendidikannya, dasar-dasar pendidikannya dari al Qur'an dan al sunnah baik sunnah amaliyah, qauliyah maupun taqririyah. Rasulullah saw.dan para sahabatnya mempraktekkan pendidikan al Qur'an dalam perilaku keseharian, berbagai hubungan-kerjasama dengan berbagai tujuan, cara dan spesifikasinya. Mereka adalah tauladan yang baik bagi generasi-genarasi yang hidup setelahnya dan berbegang pada pendidikanya dan filsafat pendidikan Islam mempunyai 
karakteristik bahwa Allah saw telah menentukan/mengariskan framenya, menentukan tujuan-tujuannya, sarana, metode dan dasar-dasarnya" (Mahjub, 1987: 28).

Berdasarkan pernyataan Abbas Mahjub di atas, praktek pendidikan Islam lebih tepatnya praktisi, tidaklah harus memahami metafisika, epistimologi dan aksiologi maupun hakekat manusia dan ilmu pengetahuan, namun cukup memahami prinsip-prinsip pendidikan, tujuan dan meneladani Allah dan Rasul-Nya. Alasannya, Al-Qur'an dan Sunnah telah mencakup filsafat pendidikan, sehingga mempraktekkan Al-Qur'an dalam kehidupan sehari-hari dengan cara meneladani Rasullah telah mempraktekkan filsafat pendidikan Islam itu sendiri.

Namun demikian, menurut hemat penulis pemaknaan yang demikian cukup berisiko karena menggiring pendidikan untuk memisahkan dimensi filsafat, ilmu, teori dan praktek. Oleh Karena itu, praktek pendidikan Islam haruslah bersandar pada filsafat pendidikan Islam.

\section{Tujuan}

Menurut Abbas Mahjub, tujuan pendidikan Islam adalah menyeimbagkan dimensi materi dan imateri atau jasmani dan rohani maupun otot dan otak peserta didik. Ia meyatakan:

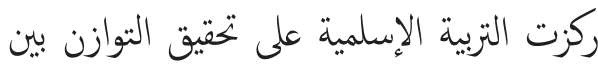

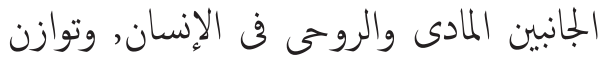
العقل والجسد, وضبطت ذلك كله بسياج من الجن وانين وتون

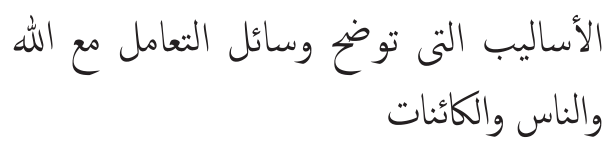

Terjemahan bebasnya:

"Pendidikan Islam memusatkan pada realisasi keseimbangan antara dua aspek materi dan immateri dalam manusia, keseimbangan antara akal dan jasad (otak) dan mengoreksi semua hal itu melalui pagar berbagai uslub (pendekatan-cara) yang menjelaskan berbagai media/sarana berhubungan dengan Allah, manusia dan alam" (Mahjub, 1987: 56).

Keseimbangan antara materi dan immateri atau jasad dan akal, hati, emosi dan sejenisnya berbeda dengan imateri dalam psikologi Barat. Jika keseimbangan jasmani dan ruhani (tepatnya emosi) di Barat bertumpa pada kesuksesan duniawi, maka tujuan pendidikan Islam adalah kesuksesan duniawi dan ukhrowi. Atas dasar ini, pendidikan Islam berbeda dengan yang lainnya, karena dalam sistem pendidikan Islam menyiapkan manusia tidak hanya untuk kehidupan di dunia tetapi juga untuk kehidupan di akhirat dengan cara membuat keseimbangan perilaku di dunia sebagai sebab untuk sukses di akhirat. Abbas mahjub menukil sebuah ayat dalam Al-Qur'an yang artinya, "Dan carilah pada apa yang telah dianugerahkan Allah kepadamu (kebahagiaan) negeri akhirat dan janganlah kamu melupakan kebahagiaanmu dari (kenikmatan) duniawi dan berbuat baiklah sebagaimana Allah telah berbuat baik kepadamu, dan 
janganlah kamu berbuat kerusakan di muka bumi. Sesungguhnya Allah tidak menyukai orang-orang yang berbuat kerusakan"'(Q.S. Al-Qasas, 28: 77).

Dalam jangka pendek, pendidikan Islam juga bertujuan untuk membentuk generasi yang terdidik, kuat dan jujur yang melaksanakan kewajiban di dunia serta mengemban tanggungjawab kemanusiaan serta mengemban inovasi ilmu dan kehidupan dalam keutamaan dan kebaikan dan menjauhkan kehinaan dan kejahatan, (merasa selalu) diawasi Allah swt. dalam sembunyi-sembunyi maupun terang-terangan sehingga dapat mewujudkan/mencapai amankeamanan, kebahagiaan, stabilitas dan kebersihan di dunia dan mendapatkan pahala dan surge di kehidupan akhirat

2. Materi

Untuk mencapai tujuan pendidikan Islam di atas, diperlukan sejumlah materi pendidikan yang dapat mengantarkan peserta didik mencapai kesuksesan dunia dan akhirat. Abbas Mahjub telah merumuskan sejumlah materi tarbiyah guna mencapai tujuan tersebut. Berikut ini adalah materi pendidikan yang dimaksud.

1) Pendidikan jasmani

Abbas mahjub mengutip pendapat Ustadz Muhammad Qutb yang menyatakana bahwa pendidikan Jasmani mencakup dimensi energy (spirit, ruh, semangat) yang tersimpan di dalam jasmani:

"Ustadz Muhammad Qutb menjelaskan, ketika membahas tentang jasmani dalam ranah pendidikan, bukan hanya hal-hal yang berkaitan dengan otot, indera maupun urat-urat belaka, namun berorientasi pada dimensienergi yang tersimpan dalam jasmani, perkembangan pribadi, daya fitrah manusia sebagai mahluk bermain (homo luden), kepekaaan sensorik dan psikomotorik. (Manhaj At-Tarbiyyah Al-Islamiyyah hal.126).

Islam mengatur kebebasan orang tua dalam menyiapkan tempat tinggal yang sehat, asupan makanan yang bergizi dan pakaian yang layak agar terbentuk perkembangan jasmani yang sehat. Hal itu akan terwujud bila orang tua memberikan nafkah yang halal yang telah diberikan oleh Allah SWT.

2) Pendidikan Rohani (Penyucian Jiwa: Ma'rifat)

Berkenaan dengan materi pendidikan ruhani, Abbas mahjub menyatakan bahwa:

"Pada umumnya ruh akan ditemukan ketika manusia menempati kedudukan ma'rifat dan mengadakan perenungan. Islam mengarahkan pendidikan ruh kepada perenungan terhadap ayat-ayat Allah secara lahir dan mengetahui apa-apa yang tersirat dari hakikat perlombaan (ibadah), penciptaan, dan makluk" (Mahjub, 1987: 173).

Selanjutnya, pendidikan Islam memperkenalkan pada manusia tentang kuatnya fitrah pembersihan jiwa, tidak ada penawaran dari penjelasan tentang jalan pengasahan perasaan manusia yang menyelamatkan dengan memperluas semua potensi biokimia dan ruh pada manusia. 
Oleh karena itu, pendidikan ruhani menekankan pada kesungguhan manusia untuk mencapai fitrah kesehatan, beribadah kepada Allah serta menjagganya serta mendidik ruhani, ketakwaan, dan sikap takut kepada Allah. Seorang muslim hendaknya memprioritaskan penumbuhan keimanan kepada Allah dan melaksanakan risalah bawa rasulullah SAW, beriman kepada malaikat, beriman kepada kitab-kitab Allah, beriman kepada para rasul, beriman kepada takdir dan ketentuan serta beriman kepada hari kiamat, hari perhitungan, surga dan neraka.

Kemudian, Abbas mahjub mengutip hadis tentang pendidikan ruhani untuk mencapai ma'rifat dengan "cinta”. Rasulullah SAW bersabda seraya menjelaskan perasaan cinta kepada Allah, bahwa cinta kepada manusia itu merupakan buah dari cinta kepada Allah dan Rasul-Nya, dan cinta karena Allah dan Rasul-Nya. Ada tiga perkara, barang siapa memilikinya niscaya akan merasakan manisnya iman (1) Hendaknya Allah dan Rasulnya lebih di cintai dari apapun, (2) mencintai seseorang karena Allah, (3) orang yang benci akan kembali pada kekufuran setelah disalamatkan Allah dari kekufuran tersebut seperti bencinya jika dilemparkan ke dalam neraka. Artinya, pendidikan ruhani bertumpu pada rasa cinta kepada Allah melaui mencintai Nabi Saw.

3. Metode Pembelajaran

Menurut Abbas mahjub, metode kependidikan merupakan cara untuk melindungi dan menjaga kecenderungan dan kecintaan para anak didik, menjaga perbedaan individual. Hal itu dikarenakan anak kecil hanya dapat memahami apa yang mungkin untuk dipahaminya, sedangkan perbedaan individual dampaknya terkadang kembali kepada karakter pendidikan, lingkungan, usia maupun kepada tingkat kecerdasan.

Islam sangat menjaga potensi perorangan hingga dalam masalah ibadah, Rasul Saw bersabda kepada para shahabat: "Apabila aku memerintahkan dengan sesuatu, maka lakukanlah sesuai kemampuan kamu, dan apabila aku mencegah kamu sekalian, maka tinggalkanlah". Sebagaimana seorang dokter, apabila ia mengobati seluruh pasiennya dengan satu pengobatan saja, niscaya banyak orang yang akan terbunuh, begitu pula dengan seorang pengajar (guru) apabila ia menunjukan para murid hanya dengan menggunakan satu cara pelatihan, ia akan merusak dan membunuh para murid, akan tetapi yang perlu diperhitungkan dan dipertimbangkan adalah pengakit yang diderita serta kondisi, usia, postur tubuh serta latihan yang dibiasakan oleh dirinya, dan ia dibina dengan latihannya itu.

Selanjutnya, Abbas mahjub mengutip sebuah hhadis yang menyatakan bahwa, "Perumpamaan petunjuk dan pengetahuan yang Allah dengannya mengutus saya, itu bagaikan hujan besar yang menyirami bumi, maka sebagian bumi itu ada yang menjadi bersih dan mau menerima air, maka rerumputan menjadi tumbuh banyak, 
sebagian dari bumi ada yang mengeras, sehingga ia bisa menampung air, dan dengannya Allah memberikan kemanfaatan kepada manusia, dengan meminum, menyirami dan untuk berciocok tanam, dan juga mengenai kelompok bumi lain, hanya saja ia merupakan bumi yang gundul lagi gersang yang tidak bisa menampung air yang tidak pula menumbuhkan rumput. Demikianlah perumpamaan orang yang belajar memahami agama Allah, maka yang Allah mengutusku untuk membawanya bermanfaat baginya, maka ia belajar dan mengajarkannya,sedangkan perumpamaan orag yang enggan dengan pengetahuan itu, maka ia tidak bisa menerima petunjuk Allah yang dengannya saya diutus."(HR. Bukhari).

\section{Evaluasi}

Menurut Abbas Mahjub, evaluasi pendidikan disesuaikan degan materi atau teori yang dipelajari, sebagaimana metode disesuaikan dengan kemampuan maupun potensi peserta didik. Karena ilmu pendidikan terdiri dari dua (dzahir dan batin), demikian pula dengan teori pendidikan (jasmani dan ruhani), maka evaluasi pendidikan Islam dibedakan berdasarkan dua teori ini.

Abbas Mahjub merekomendasikan model evaluasi pendidikan jasmani seperti: uji ketangkasan dalam olah fisik, seperti memanah, berkuda dan berenang. Adapun model evalausi pendidikan ruhani, emosi, akal dan sejenisnya adalah dengan Reward dan punisment. Model evaluasi ini merupakan sarana yang menyelamatkan dalam mewujudkan emosi dengan janji dan ancaman tetang keutamaan dan keburukan, serta perbutan jelek dengan reward dan punisment, sarananya dan tata caranya.

Berdasarkan hasil penelitian di atas dengan berdasar pada kerangka teori yang diguanakn dan metode penelitian yang diterapkan, dapat disusun sebuah konstruksi filsafat tarbiyah sebagaiman dilukiskan berikut ini.

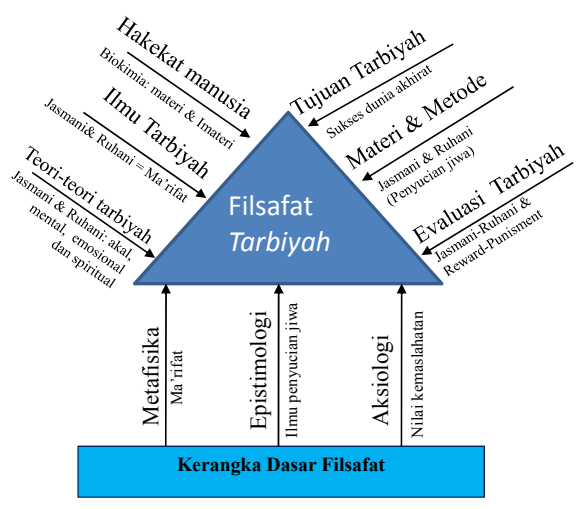

Gambar: 2

Konstruksi Filsafat Tarbiyah

Gambar di atas melukiskan konstruksi filsafat tarbiyah menurut Abbas Mahjub. Konstruksi itu dapat dijelaskan demikian. Pertama, filsafat tarbiyah bersumber pada Al-Qur'an dan Hadis. Kerangka dasar filsafat tarbiyah mencakup metafisika, epistimologi dan aksiologi. Metafisika filsafat tarbiyah adalah ma'rifat, epistimologi filsafat tarbiyah adalah penyucian jiwa, dan aksiologi filsafat tarbiyah adalah nilai kemaslahatan.

Kedua, hakekat manusia adalah biokimia yang terdiri dari dimensi imateri 
dan materi. Ilmu tarbiyah adalah ilmu ma'rifat dan teori yang dapat dibangun adalah teori pembelajaran jasmani, ruhani (mental, spiritual dan emosional).

Ketiga, praktek filsafat tarbiyah yang mencakup tujuan, materi, metode dan evaluasi. Tujuan filsafat tarbiyah adalah mengantarkan peserta didik sukses dunia dan akhirat. Materi yang harus diajarkan adalah jasmani dan ruhani, metodenya adalah penyucian jiwa dan evaluasinya mengguanakan reward dan punishment.

\section{PENUTUP}

Filsafat tarbiyah bersumber pada Al-Qur'an dan hadis dan dibangun di atas tiga kerangka dasar dasar, yakni ma'rifat (metafisika), penyucian jiwa (epistimologi) dan kemaslahatan (aksiologi). Berdasar ketiga kerangka dasar ini, dapat dibangun cara pandang tentang hakekat manusia, ilmu tarbiyah dan teori tarbiyah. Hakekat manusia dalam perspektif tarbiyah adalah biokimia, ilmu tarbiyah adalah ma'rifah dan teori tarbiyah adalah jasmani dan ruhani. Selanjutnya, filsafat tarbiyah dapat dipraktekkan melalui tujuan, materi, metode dan evaluasi. Tujuan filsafat tarbiyah adalah mengantarkan peserta didik sukses dunia akhirat. Materi yang harus diajarkan adalah jasmani dan ruhani, metode yang digunakan adalah penyucian jiwa dan evaluasi yang diterapkan adalah reward dan punishment.

Hendaknya penelitian ini dilanjutkan pada upaya-upaya merekonstruksi filsafat tarbiyah dari filsuf-filsuf Muslim yang lain, seperti Al-Ghazali, Ibn Sina, Ibn Khaldun, dan lain-lain. Selanjutnya, hasil-hasil penelitian tersebut hendaknya dikonseptualisasikan atau siabstraksikan sehingga menjadi konstruksi filsafat tarbiyah universal dan dapat digunakan untuk pengembagan ilmu di Fakultas Tariyah dan Keguruan di lingkungan PTAI.

\section{DAFTAR PUSTAKA}

Arif, Mahmud, 2011, Filsafat Pendidikan Islam, Yogyakarta: Fakultas Tarbiyah dan Keguruan UIN Sunan Kalijaga.

Mulyasa, 2007, Kurikulum Tingkat Satuan Pendidikan (KTSP), Bandung: Rosda Karya.

Barnadib, Imam, 1994, Filsafat Pendidikan, Sistem dan Metode, Yogyakarta: Andi Offset.

George, Knight R., 2007, Filsafat Pendidikan, Trj. Mahmud Arif, Yogyakarta: Gama Media dan CDIE UIN Sunan Kalijaga.

Mahjub, Abbas, 1987, Us Ül Al Fikriy Al Tarbawiy F̄̄ Al Islām, Beirut: Muassasah Ulum Alquran.

Mulkhan, Abdul Munir, 1993, Paradigma Intelektual Muslim, Pengantar Filsafat Pendidikan Islam dan Dakwah, Yogyakarta: Sipress.

Qomar, Mujamil, 2002, Epistimologi Pendidikan Islam, Jakarta: Erlangga.

Qutb, Muhammad, 1988, Sistem Pendidikan Islam, Trj. Salman Harun, Bandung: Al-Ma'arif. 